\title{
Vegetation Management by Manual and Mechanical Means in Alberta Boreal Forests ${ }^{1}$
}

\author{
by G. Ehrentraut and K. Branter ${ }^{2}$
}

\begin{abstract}
Vegetation management by non-chemical means is most critical and effective during site preparation as well as after crop establishment. A key to successful reforestation has been quality site preparation followed by planting. In Alberta's boreal forests, three methods of site preparation have proven very successful in controlling vegetation competition and ensuring good regeneration results:
\end{abstract}

1. Double Discing: controls grass and deciduous species on moist sites;

2. Marttiini Plow: controls deciduous species on moist-to-wet sites;

3. Ripper Plow: controls deciduous species on wet sites.

\section{Résumé}

L'aménagement de la végétation par des moyennes non chimiques est la plus critique et la plus effectif lorsqu'on l'effectue au cours de la préparation du site ou après l'établissement du peuplement. Une clef pour réussir au reboisement a été de préparer bien le site avant de la planter. Dans les forêts boréales de l'Alberta, on a réussi très bien à contrôler la compétition de végétation et à assurer de bons résultats du reboisement avec trois méthodes de préparation du site:

1. Déchaumer deux fois: contrôle les graminées et les espèces feuillues sur les sites humides;

2. Charrue Marttiini: contrôle les espèces feuillues sur les sites humides à mouillés:

3. Défonceuse: contrôle les espèces feuillues sur les sites mouillés.

\section{Introduction}

In Alberta, the current harvest level is over 30,000 hectares annually. This occurs on sites ranging from the boreal mixedwood where white spruce/aspen is the dominant species mix, to the foothills where lodgepole pine is the dominant species.

To generalize, the major competitors to conifer crop trees are viewed as grass in the early establishment phase of regeneration, and hardwoods in later stages of development. Reforestation in Alberta has been focused for some time to met a minumum stocking standard within 10 years of harvest. To this end, success rates stand at some $96 \%$. That is, $96 \%$ of cutovers 10 years old and older have met the required stocking standard.

Relatively little vegetation management has been carried out until recently, as most programs concentrated on establishment through scarification, planting and seeding. However, with recent interest nationally and locally in performance of crop trees, vegetation management is receiving more attention.

In Alberta, detailed surveys have been completed on cutovers previously considered satisfactorily regenerated (SR). These surveys focused on the crop tree performance, density, and stocking. The results of these surveys have generated much discussion on the need for a new performance standard as well as the need for vegetation management as a normal component of the regeneration process.

Before reviewing our activities in manual/mechanical vegetation management, let me briefly review herbicide use in Alberta. In the early 1980s use of chemical herbicide was

\footnotetext{
"Paper presented at the Joint Technical Session, "Vegetation management problem or challenge," of the Forest Ecology, Forest Pest Management, and Silvicul ture and Tree Improvement Working Groups at the CIF/IFC Annual Meeting Kananaskis, Alberta, October 1989.

${ }^{2}$ Reforestation Branch, Alberta Forest Service, Department of Forestry, Lands and Wildlife, Edmonton, Alberta
}

initiated on a small sscale. Trials of 2,4-D, Velpar and Vision were established. Various application techniques have been utilized, including aerial, ground, and spotgun. The use of these herbicides is viewed as a cost-effective, environmentally-safe means of vegetation control, providing good conifer crop tree response, and control of target species, while maintaining a mixedwood stand. The public reaction to herbicide use here has not been favourable, however, and as indicated in Table 1, relatively little is now being used.

Table 1. Vegetation management in Alberta

\begin{tabular}{llc}
\hline Years & Herbicide & Manual/Mechanical \\
\hline $1980-84$ & 891 hectares & 3105 hectares \\
1985 & 635 & 837 \\
1986 & 992 & 92 \\
1987 & 87 & 2109 \\
1988 & 4 & 9946 \\
Total & 2609 hectares & 16089 hectares \\
\hline
\end{tabular}

We shall continue to build credibility for the use of herbicides in forest management, and hope to be able to add it to our arsenal of treatment techniques. In the short term, we implement some of the alternatives to herbicide use, and are attempting to document the best opportunities for manual/mechanical methods.

\section{Site Preparation}

Experience has taught us that one of the most important steps in properly reforesting a cutover area is still adequate site preparation. Effective site preparation can help make good seedling performance and adequate vegetation control possible. We need to provide every opportunity in initial treatments for crop seedlings to out-compete the non-crop vegetation. By reducing or removing competing vegetation, newly established conifers have the opportunity to obtain a quick start over faster growing non-crop vegetation. Height growth of plantations on areas scarified with the Marttiini plow is four times greater then than on areas prepared with the 
Bracke plow. We feel that the elevated planting position, soil warming and reduced competition have a great impact on seedling growth here.

The longer the period between harvesting and seedling establishment, the greater a problem competing vegetation is likely to be. On boreal sites, planting with proper site preparation is considered the primary regeneration method to ensure success of crop trees.

Using certain site preparation methods to control vegetation competition has been very successful in providing not only good survival results, but also excellent growth:

- Moist sites: double discing has in some cases controlled the aspen regrowth for up to five years. On these sites, white spruce seedlings have reached $1.5 \mathrm{~m}$ height in less than six years.

- Moist-to-wet sites: Marttiini plow scarification is capable of reducing aspen suckering to $1 / 3$ of its original density; it provides elevated microsites which help raise soil temperature, and provides drainage on wetter sites. Generally, survival is improved on cutovers that are Marttiini-plowed and planted, with growth averaging $70 \%$ better with such scarification compared with Bracke scarification.

- Wet sites that are accessible in the winter only, have been successfully site prepared using a ripper plow. Aspen vegetation is controlled for several years, allowing regeneration to become established. Grass competition is more difficult to control with mechanical methods of site preparation. Areas prone to grass competition must be quickly planted and monitored closely for possible follow up treatment at a later date.

\section{Manual/Mechanical}

\section{Manual Tending}

Alberta Forest Service (AFS) activities in manual/ mechanical cleaning and tending have been directed towards large areas at plantations that were established between 1979 and 1986. Some 50,000 hectares of plantations were established in northern Alberta using various treatment techniques. All of these plantations were basically aspen conversion projects on old burn areas. Most of these plantations are 4-10 years old and require vegetation control to varying degrees, depending on scarification techniques. Hardwoods are the serious competition, with densities ranging from almost nil on cultivated sites to 50,000 stems per hectare on areas of minimal scarification. With recent documentation of declining crop tree vigour, and an increasing snowshoe hare population, these areas have been considered a priority for vegetation control.

In Alberta in 1989, the AFS cleaned and tended about 1600 hectares with brush saws to release conifers in young plantations. The average cost was $\$ 548$ per hectare with a treatment rate of 0.31 hectares/man/day. According to Holmgren (1988), the clearing of deciduous species on a project in the Grande Prairie area resulted in a $54 \%$ slash cover approximately 0.3 metres deep, and $13 \%$ of the conifers were deeply covered by the slash. Seedling damage due to slash cover was a more serious problem than direct saw damage. Brush cutting will result in damage to some conifers, and estimates of this damage should be included when comparing brush saws to alternative methods of release.

Mechanical vegetation control is also used on boreal forest sites. Road-side grass cutters have been modified to cut aspen overstory in young spruce plantations. The objective is to remove the overstory above the conifers to allow in more light and reduce the habitat for snowshoe hares. This has been a very successful and cost-effective method of mechanical control of aspen in small young plantations. In two years, AFS Gyro mowed 6689 hectares at an average cost of $\$ 70$ hectare with a treatment rate of 17 hectares/ machine/day.

Preliminary results indicate aspen numbers are reduced possibly due to the high degree of bark scraping and stem mutilation. The remaining aspen were not completely killed and some apical dominance remained which prevented resuckering. New aspen growth from remaining live stems was relatively short and deformed, and many were infected by shepherd's crook which could further increase aspen mortality

The use of this mechanical method is limited due to several factors:

(1) Crop trees must be uniform in size and less than the cutting height of Gyromower.

(2) Site accessibility - mechanical mower cannot operate on rough moist ground.

(3) Vegetation height and diameter limits the operability of the mower.

(4) Seedlings will require more than one release treatment in the future as the aspen is cut off above the seedling.

Girdling is another method of manual control we are currently testing. Results indicate that cost-effective girdling depends on stem diameter and number of stems per hectare. Currently the number of areas that fall within this range is not very great, but we feel that there may be some limited potential for girdling.

\section{Prescription}

The objective in conifer release is not necessarily to kill established competition, but to reduce the competing vegetation to increase the amount of light reaching the conifers, and to decrease competition for nutrients. To accomplish this, a high percentage of defoliation, a fair amount of tip kill, and minimum resprouting (Miller 1985) is required.

Established seedlings seldom die from aspen competition, although growth loss may be substantial. Miller (1985) states that white spruce rotations may be lengthened by as much as 20 years due to competition. More importantly, white spruce seedlings immediately adjacent to, or as an understory to, an aspen canopy are most vulnerable to damage by the snow hare. Conifer release through manual or mechanical means not only has biological benefits for conifer growth, but offers habitat manipulation that reduces the cover, and thus, decreases hare damage potential (Johnson 1986).

When properly used, release treatment should be conducted when plantation seedlings are vigorous enough to respond to being released (usually age five). This should be done before mortality and growth losses have occurred. Information on growth and height is needed to guide the planning and scheduling of release treatments. To get good conifer response while minimizing release work, seedlings should be growing at least 15 centimetres per year.

Three treatment types are identified, stratified by the height of the tree (Figure 1): 


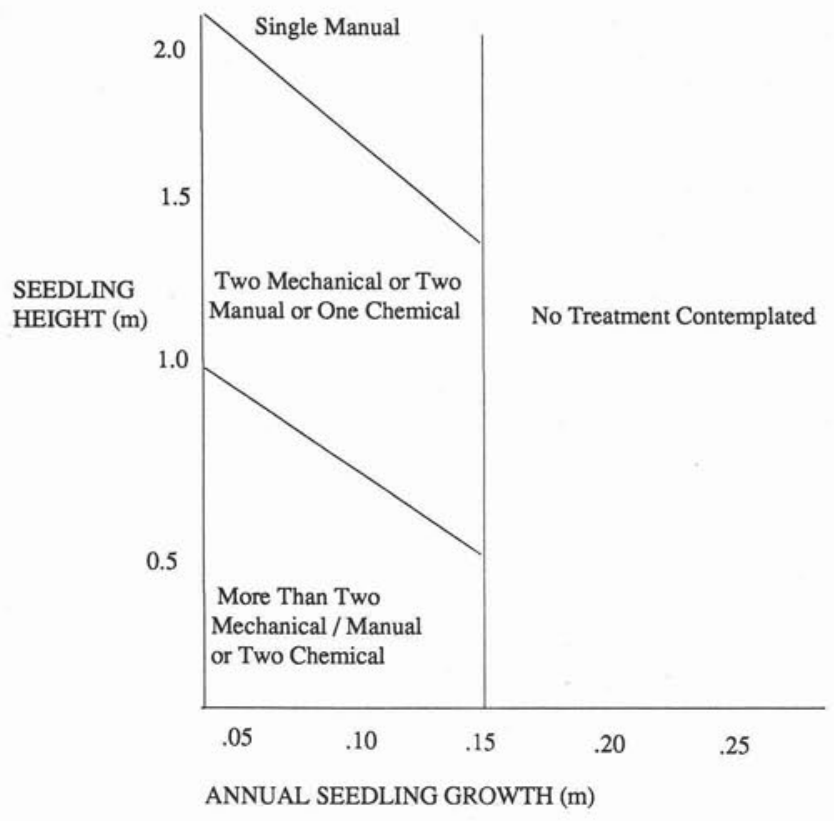

Figure 1. A cleaning and tending guide.

- First, if the crop tree is small and not growing well, several treatments are required to bring the seedlings through the competition. Here, herbicides have the greatest utility as they provide longer control, especially of grass.

- Second, if the seedling is less than two metres and growing, it may require a couple of manual or mechanical release

treatments to get it above the competition. Aspen can grow a metre a year, quickly overtopping the conifer and putting it back in a suppressed condition.

- Third, it the spruce is over two metres, a single manual cleaning may suffice to bring the crop tree through to maturity. ${ }^{1}$

\section{Conclusion}

Effective vegetation management for conifer release using manual or mechanical practices requires that plantation seedlings are vigorous enough to enable the conifers to respond to being released and that they are tall enough so that the competition does not quickly overtop them. Manual brushsaw and mechanical gyro-mowing are two of the more common non-chemical conifer release techniques used in Alberta.

\section{References}

Holmgren, Sylvi D. 1988. Stand cleaning with Husquvarna $165 \mathrm{RX}$ cleaning saws in northern Alberta. FERIC Silvi Tech Note TN-116.

Johnson, H.J. The release of white spruce from trembling aspen overstorys. A review of available information and silviculture guidelines prepared for Dept. of Nat Resour, For Branch Manitoba.

Miller, Daniel T. 1985. Conifer release in the inland northwest Effects p. 17-24 in weed control for forest productivity in the interior west. Symp Proce Spokane, WA February 5-7, 1985. Washington State University.

${ }^{1}$ T.J. Drew, Alberta Forestry Service, Pers. Comm., Feb. 1988

\section{NOTICE}

\section{OTTAWA, ONTARIO - CANADA'S CAPITAL SITE OF THE 1990 ANNUAL GYPSY MOTH REVIEW}

360 mooney street thunder bay, ontario P7B 5R4

\section{FOREST RESOURCE}

- Inventory, Surveys and Evaluations

\section{REFORESTATION EQUIPMENT} - Sales Service Parts Repair

\section{REGENERATION \& SITE PREPARATION} - Contract Assessment Consulting

Tele 807-344-0811 Fax 807-345-3440 Toll free 1-800-465-3001

\section{October 22nd-25th}

For further information and/or registration kit, please contact:

Rosanne Smith, Secretary/Treasurer Gypsy Moth Management Committee R.R. \#1

Battersea, Ontario KOH $1 \mathrm{HO}$

Telephone (613) 353-1223

Facsimile (613) 353-1224 